\title{
Pengaruh Kinerja Keuangan Terhadap Alokasi Belanja Modal dan Pertumbuhan Ekonomi Kabupaten/Kota di Provinsi Jawa Tengah
}

\author{
Joni Kristian Firdi Yanto', Susi Astuti ${ }^{2}$ \\ ${ }^{1}$ Sekolah Tinggi Ilmu Ekonomi Putra Bangsa \\ ${ }^{2}$ Sekolah Tinggi Ilmu Ekonomi Putra Bangsa \\ Email: jonikristian11@gmail.com
}

\section{ARTICLE INFO}

Article History:

Received: March 10th 2020

Accepted: March 11th 2020

Published: June 30th 2020

Keywords:

Keuangan, Alokasi Belanja

Modal, Pertumbuhan

Ekonomi

\begin{abstract}
Penelitain ini bertujuan untuk menganalisis pengaruh Kinerja Keuangan terhadap Alokasi Belanja Modal pada pemerintah daerah Kabuaten/Kota di Provinsi Jawa Tengah; serta pengaruh Kinerja Keuangan terhadap Pertumbuhan Ekonomi pada pemerintah daerah kabupaten/kota di Provinsi Jawa Tengah. Penelitian ini menggunakan data sekunder berupa Laporan Realisasi Anggaran Pendapatan dan Belanja Daerah dan Produk Domestik Regional Bruto tahun 2016 sampai dengan tahun 2018. Pengujian hipotesis dalam penelitian ini menggunakan Structural Equation Modelind (SEM) dengan bantuan program Partial Least Square (PLS), dengan pengujian berupa Convergent Validity, Descriminan Validity, Internal Consistency Reliability, Hypotesis Testing. Hasil penelitian ini menunjukan bahwa Kinerja Keuangan berpengaruh signifikan terhadap Alokasi Belanja Modal dan Pertumbuhan Ekonomi. Implikasi dari penelitian ini adalah bahwa pemerintah daerah harus senantiasa meningkatkan Kinerja Keuangannya karena berdampak pada peningkatan Alokasi Belanja Modal dan Pertumbuhan Ekonomi.
\end{abstract}

\section{Pendahuluan}

Memasuki perkembangan perekonomian pada era reformasi pada pertengahan tahun 1998, timbul tuntutan pelaksanaan otonomi yang lebih luas, nyata, dan bertanggung jawab kepada daerah. Adanya tuntutan tersebut, pelaksanaan Reformasi Birokrasi diperkuat dengan diberlakukannya UndangUndang No. 32 tahun 2004 tentang pemerintahan daerah dan Undang-Undang No. 33 tahun 2004 tentang perimbangan keuangan antara pemerintah pusat dengan pemerintah daerah. Hal itulah yang membuat terjadinya proses peralihan dari sistem dekonsentralisasi ke sistem desentralisasi yang disebut dengan otonomi daerah.

Otonomi Daerah adalah kebebasan yang diberikan oleh Pemerintah Pusat kepada Pemerintah Daerah untuk membuat peraturan daerah, menyusun, mengelola dan melaksanakan kebijakan serta keuangan daerah. Tujuan pelaksanaan Otonomi Daerah adalah meningkatkan kemandirian daerah, memperbaiki 
transparansi dan akuntabilitas publik atas pengelolaan keuangan daerah, meningkatkan partisipasi publik dalam pembangunan daerah, meningkatkan efesiensi dan efektifitas pengelolaan keuangan dan pelayanan publik, serta mendorong demokratisasi di daerah.

Pengelolaan keuangan daerah yang baik akan berpengaruh terhadap kemajuan suatu daerah dan mendorong pertumbuhan ekonomi di daerah tersebut. Analisis kinerja keuangan pada dasarnya dilakukan untuk menilai kinerja di masa lalu dengan melakukan analisis sehingga diperoleh posisi keuangan yang mewakili realisasi entitas dan potensi kinerja yang berkelanjutan.

Salah satu belanja yang dilakukan oleh pemerintah daerah adalah belanja modal. Belanja modal adalah pengeluaran dalam rangka pembelian aset tetap berwujud dengan nilai manfaat lebih dari satu tahun. Belanja modal merupakan salah satu cara untuk mewujudkan tujuan otonomi daerah yaitu meningkatkan kesejahteraan dan pelayanan kepada masyarakat, hal ini dapat disimpulkan bahwa belanja modal sangat penting karena membantu mewujudkan kesejahteraan masyarakat.

Tabel 1. Realisasi belanja di Provinsi Jawa Tengah tahun 2016-2018 (dalam milyar Rupiah)

\begin{tabular}{cccc}
\hline KETERANGAN & $\mathbf{2 0 1 6}$ & $\mathbf{2 0 1 7}$ & $\mathbf{2 0 1 8}$ \\
\hline Belanja Pegawai tidak langsung & 2.568 & 6.092 & 6.468 \\
Belanja Barang dan Jasa & 2.493 & 3.381 & 4.043 \\
Belanja Modal & 2.816 & 1.455 & 1.682 \\
\hline
\end{tabular}

Sumber : DJPK kemenkeu (2019)

Berdasarkan data tersebut menunjukkan belanja pegawai masih mendominasi belanja daerah di provinsi Jawa Tengah pada tahun 2017-2018. Hal tersebut disebabkan adanya Peraturan Gubernur Jawa Tengah No. 06 Tahun 2017 tentang perubahan kedua atas Peraturan Gubernur Jawa Tengah No. 43 Tahun 2015 tentang pemberian Tambahan Penghasilan Pegawai (TPP) di lingkungan pemerintahan Jawa Tengah. Hal ini dilakukan karena dengan meningkatnya TPP dapat mengurangi korupsi dikalangan pegawai daerah. Berbeda dengan Belanja modal yang mengalami fluktuasi di tahun 20162018 karena Anggaran Belanja Daerah yang lebih diprioritaskan ke Belanja Tidak Langsung.

Pertumbuhan ekonomi merupakan proses perubahan kondisi perekonomian suatu daerah menuju kondisi yang lebih baik. Peningkatan pertumbuhan ekonomi ditandai dengan kenaikan kapasitas produksi dalam perekonomian suatu daerah yang dapat meningkatkan pendapatan daerah. Produk Domestik Regional Bruto (PDRB) merupakan salah satu indikator penting untuk mengetahui kondisi ekonomi di suatu daerah dalam satu periode tertentu.

Produk Domestik Regional Bruto atas dasar harga konstan menggambarkan nilai tambah barang dan jasa dihitung dengan menggunakan harga yang berlaku pada satu tahun tertentu sebagai dasar. Biasanya tahun yang dijadikan harga dasar diubah setiap sepuluh tahun sekali yang bertujuan untuk pembaruan. PDRB atas harga konstan juga bisa untuk melihat pertumbuhan ekonomi yang terjadi di sebuah daerah dari tahun ke tahun.

Tabel 2. Produk domestik regional bruto atas dasar harga konstan tahun 2010 menurut Provinsi tahun 2016-2018 (dalam milyar Rupiah)

\begin{tabular}{cccc}
\hline Provinsi & $\mathbf{2 0 1 6}$ & $\mathbf{2 0 1 7}$ & $\mathbf{2 0 1 9}$ \\
\hline DKI Jakarta & 1.539 .917 & 1.635 .367 & 1.736 .196 \\
Jawa Barat & 1.275 .619 & 1.343 .864 & 1.419 .689 \\
Jawa Tengah & 849.099 & 893.750 & 941.283 \\
DI Yogyakarta & 87.686 & 92.302 & 98.027 \\
Jawa Timur & 1.405 .564 & 1.482 .300 & 1.563 .756
\end{tabular}

Sumber : Badan Pusat Statistik (2019) 
Berdasarkan data tersebut menunjukan PDRB atas dasar harga konstan, Jawa Tengah memiliki Produk Domestik Regional Bruto yang rendah dibandingkan dengan Provinsi DKI Jakarta, Jawa Barat dan Jawa Timur. Produk Domestik Regional Bruto di Jawa Tengah terus mengalami peningkatan di tahun 2016-2018. Hal ini dikarenakan adanya sejumlah peningkatan dari berbagai sisi seperti: sisi produksi (sektor pertanian dan perkebunan, sektor perikanan dan industri, dan sektor pariwisata). Sisi pengeluaran dengan pertumbuhan tertinggi dicapai oleh komponen ekspor (tekstil dan barang tekstil, kayu dan barang dari kayu, dan hasil pabrik).

\section{Kajian Teori dan Telaah Literatur}

\section{Kinerja keuangan}

Menurut Mahmudi (2016:25) kinerja keuangan pemerintah daerah adalah keluaran keluaran/hasil dari kegiatan/promosi yang akan atau telah dicapai sehubungan dengan penggunaan anggaran daerah dengan kuantitas dan kualitas yang terukur, kemampuan daerah dapat diukur dengan menilai efisiensi atas pelayanan yang diberikan kepada masyarakat. Dari beberapa pengertian diatas dapat disimpulkan bahwa kinerja keuangan pemerintah daerah adalah tingkatan capaian dari suatu hasil kerja di bidang keuangan daerah yang meliputi anggaran dan realisasi anggaran dengan menggunakan indikator keuangan yang telah ditetapkan melalui suatu kebijakan atau ketentuan perundangundangan selama periode anggaran. Hal tersebut bertujuan untuk mengetahui kemampuan suatu daerah dalam mengelola keuangannya.

Dalam organisasi pemerintahan untuk mengukur kinerja keuangan ada beberapa ukuran kinerja, yaitu rasio kemandirian, rasio efektifitas, rasio keserasian, rasio drajad desentralisasi fiskal, rasio ketergantungan keuangan, rasio Debt Service Coverage, rasio efisiensi keuangan daerah, rasio pertumbuhan.

Kemandirian keuangan daerah (otonomi fiskal) menunjukkan tingkat kemampuan suatu daerah dalam membiayai sendiri kegiatan pemerintahan, pembangunan, dan pelayanan kepada masyarakat yang telah membayar pajak dan restribusi sebagai sumber pendapatan yang diperlukan daerah. Rasio kemandirian keuangan daerah dapat dilihat dari besarnya pendapatan asli daerah dibandingkan dengan pendapatan daerah yang berasal dari sumber lain (pendapatan transfer) seperti bantuan pemerintah pusat ataupun dari pinjaman.

Rasio Efektivitas PAD menggambarkan kemampuan pemerintahan daerah dalam merealisasikan PAD yang direncanakan dan dibandingkan dengan target yang ditetapkan berdasarkan potensi rill daerah. Semakin tinggi Rasio Efektivitas PAD, maka semakin baik kinerja pemerintahan daerah. Rasio Keserasian menggambarkan bagaimana pemerintahan daerah memprioritaskan alokasi dananya pada belanja operasi dan belanja modal secara optimal. Semakin tinggi presentase dana yang dialokasikan untuk belanja operasi berarti presentase belanja modal yang digunakan untuk menyediakan sarana prasarana ekonomi masyarakat cenderung semakin kecil.

Rasio Derajat Desentralisasi Fiskal dihitung berdasarkan perbandingan antara jumlah Pendapatan Asli Daerah (PAD) dengan Total Pendapatan Daerah (TPD). Rasio ini menunjukan derajat kontribusi PAD terhadap total pendapatan daerah. Semakin tinggi kontribusi PAD maka semakin tinggi kemampuan pemerintah daerah dalam penyelenggaraan desentralisasi.

Rasio ketergantungan keuangan dihitung dengan membandingkan jumlah pendapatan transfer yang diterima oleh penerimaan daerah dengan total pendapatan daerah. Semakin 
tinggi rasio maka semakin besar tingkat ketergantungan pemerintahan daerah terhadap pemerintahan pusat.

Debt Service Coverage Ratio (DSCR) merupakan rasio untuk mengukur kemampuan pemerintah daerah dalam membayar kembali pinjaman daerah. Rasio ini sangat diperlukan apabila pemerintah daerah berencanauntuk mengadakan utang jangka panjang. Berdasarkan rasio ini, pemerintah daerah dinilai layak untuk melakukan pinjaman daerah apabila nilai DSCR-nya minimal sebesar 2,5. Jika nilai DSCR kurang dari 1 maka hal itu mengidentifikasikan terjadinya arus kas negatif, yang berarti pendapatan tidak cukup untuk menutup seluruh beban utang berupa angsuran pokok dan bunga.

Rasio Efisiensi Keuangan Daerah menggambarkan perbandingan antara besarnya biaya yang dikeluarkan untuk memperolah pendapatan dengan realisasi pendapatan yang diterima. Kinerja Keuangan Pemerintahan Daerah dalam melakukan pemungutan pendapatan dikatagorikan efisien apabila rasio yang dicapai kurang dari 1 (satu) atau di bawah $100 \%$. Semakin kecil rasio efisiensi keuangan daerah berarti kinerja keuangan pemerintahan daerah semakin baik.

Mahmudi (2010:138) rasio pertumbuhan bermanfaat untuk mengetahui apakah pemerintahan daerah dalam tahun anggaran bersangkutan atau selama beberapa periode anggaran, kinerja anggarannya mengalami pertumbuhan pendapatan atau belanja secara positif atau negatif. Rasio ini mengukur seberapa besar kemampuan pemerintahan daerah dalam mempertahankan dan meningkatkan keberhasilanya yang telah dicapai dari satu periode ke periode berikutnya

\section{Belanja modal}

Belanja modal merupakan pengeluaran pemerintah daerah yang manfaatnya lebih dari satu tahun anggaran dan akan menambahkan aset atau kekayaan daerah dan barakibat menambah belanja yang bersifat rutin. Belanja Modal dapat disimpulkan sebagai pengeluaran yang dilakukan dalam rangka pembentukan modal yang sifatnya menambahkan aset tetap/inventaris yang memberikan manfaat lebih dari satu periode akuntansi.

Belanja modal diklasifikasikan dalam dua kelompok. kelompok pertama adalah belanja publik yaitu belanja yang memanfaatnya dapat langsung dinikmati masyarakat misalnya: pembangunan jembatan, pembelian mobil ambulan yang dipergunakan untuk umum, dan lain sebagainya. Kelompok kedua adalah belanja aparatur yaitu belanja yang manfaatnya tidak langsung untuk masyarakat tapi dapat dirasakan langsung oleh aparatur misalnya: pembangunan gedung dewan, pembelian mobil dinas, dan lain sebagainya. Hampir semua anggaran belanja modal mengandung komitmen adanya pengeluaran dalam jangka yang cukup panjang. Belanja modal sangat erat kaitanya dengan investasi yang dilakukan oleh pemerintah daerah.

\section{Pertumbuhan ekonomi}

Pertumbuhan Ekonomi merupakan perkembangan kegiatan dalam perekonomian yang menyebabkan meningkatnya produksi barang dan jasa yang ada di masyarakat dan membuat kemakmuran masyarakat meningkat. Pertumbuhan ekonomi dapat diartikan juga sebagai kenaikan Gross Domestic Product (GDP) atau Gross National Product (GNP) tanpa memandang apakah kenaikan itu lebih besar atau lebih kecil dari tingkat pertumbuhan penduduk atau perubahan struktur ekonomi terjadi atau tidak.

Produk Domestik Regional Bruto (PDRB) merupakan salah satu indikator penting untuk mengetahui kondisi ekonomi di salah satu daerah dalam satu periode tertentu, baik atas 
dasar harga berlaku maupun atas dasar harga konstan. Perhitungan produk domestik regional bruto secara konseptual menggunakan tiga macam pendekatan, yaitu pendekatan produksi, pendekatan pengeluaran, dan pendekatan pendapatan. Pertumbuhan ekonomi dalam penelitian ini diproksi dengan Produk Domestik Regional Bruto (PDRB) per kapitan.

\section{Pengembangan Hipotesis}

Dengan diberlakukannya otonomi daerah menyebabkan pemerintah daerah mempunyai wewenang untuk mengelola keuangan daerahnya sendiri. Pengelolaan keuangan daerah yang baik akan ditunjukan dengan kinerja keuangan yang baik pula. Kinerja keuangan yang baik diharapkan dapat meningkatan alokasi belanja modal pemerintah daerah untuk menyediakan sarana dan prasarana yang dibutuhkan oleh masyarakat. Kinerja Keuangan yang baik juga diharapkan dapat digunakan untuk mengukur kontribusi anggaran pemerintah daerah terhadap pertumbuhan ekonomi di daerah tersebut.

\section{Pengaruh kinerja keuangan dengan alokasi belanja modal}

Belanja modal merupakan angka yang memberi gambaran tentang usaha pemerintahan daerah dalam meningkatkan pembangunan daerahnya. Semakin besar anggaran belanja modal yang diberikan maka hal tersebut mengambarkan besarnya pemerintah daerah untuk meningkatkan pertumbuhan pembangunan daerahnya. Kemampuan daerah dalam meningkatkan anggaran belanja modal erat hubungannya dengan kemampuan daerah untuk meningkatkan kinerja keuangannya. Kinerja keuangan yang meningkat pada suatu daerah selaras dengan meningkatnya alokasi belanja modal di daerah tersebut.

\section{Pengaruh kinerja keuangan dengan pertumbuhan ekonomi}

Menurut Sularso, et al. (2011) dalam penelitiannya menyimpulkan bahwa faktor yang mempengaruhi pertumbuhan ekonomi secara tidak langsung dipengaruhi oleh kinerja keuangan daerah salah satunya adalah rasio derajad desentralisasi. Semakin baik kinerja keuangan maka semakin baik juga kemampuan pemerintah daerah untuk meningkatkan pertumbuhan ekonomi.

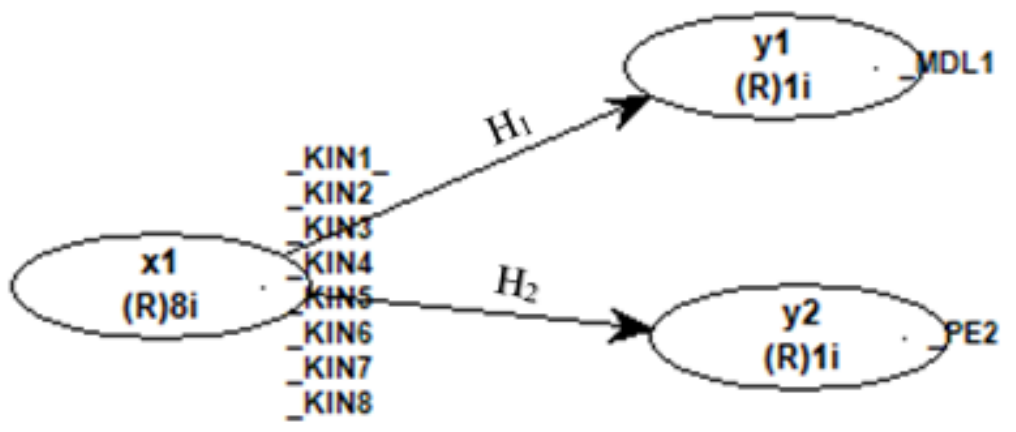

Gambar 1. Model penelitian

\section{Metode Penelitian}

\section{Populasi dan teknik pengambilan sampel}

Populasi penelitian seluruh Kabupaten dan Kota ya ada di Provinsi Jawa Tengah, yang berjumlah 35 Kabupaten/Kota. Seluruh Kabupaten/Kota dijadikan sampel dalam penelitian 
ini, karena penelitian ini tidak dimaksudkan untuk menggeneralisasikan suatu permasalahan tetapi menguji pengaruh antara variabel yang diteliti. Penelitian menggunakan data sekunder berupa laporan keuangan daerah tahun 2016 - 2018.

\section{Definisi oprasional variabel}

\section{Alokasi belanja modal}

Menurut Peraturan Mentri Dalam Negeri No. 59 tahun 2007 pasal 53 menyatakan bahwa belanja modal digunakan untuk pengeluaran yang dilakukan dalam rangka pengadaan aset tetap berwujud yang mempunyai nilai manfaat lebih dari 12 bulan untuk digunakan dalam kegiatan pemerintahan. Alokasi Belanja Modal dihitung dengan rumus sebagai berikut:

Belanja Modal $=\frac{\text { Belanja Modal }}{\text { Total Belanja dalam APBD }} \times 100 \%$

\section{Pertumbuhan ekonomi}

Pertumbuhan ekonomi merupakan perkembangan kegiatan dalam perekonomian yang menyebabkan barang dan jasa yang diproduksi di dalam masyarakat bertambah yang menyebabkan kemakmuran masyarakat meningkat dan semakin tingginya tingkat kemandirian daerah tersebut. Rumus untuk Menghitung Pertumbuhan Ekonomi yaitu :

Pertumbuhan Ekonomi $=\frac{\text { PDRBt }- \text { PDRBt }-1}{\text { PDRBt }-1} \times 100 \%$

\section{Kinerja keuangan}

Kinerja keuangan adalah suatu ukuran kinerja yang menggunakan indikator keuangan. Salah satu alat ukur kinerja keuangan pemerintah daerah adalah analisis rasio keuangan daerah yang merupakan inti pengukuran kinerja sekaligus konsep pengelolaan organisasi pemerintah untuk menjamin dilakukanya pertanggungjawaban publik oleh lembagalembaga pemerintah kepada masyarakat.Kinerja keuangan pemerintah daerah dapat diukur berdasarkan :

\section{a. Rasio kemandirian keuangan daerah}

Kemandirian keuangan daerah (otonomi fiskal) menunjukkan tingkat kemampuan suatu daerah dalam membiayai sendiri kegiatan pemerintahan, pembangunan, dan pelayanan kepada masyarakat yang telah membayar pajak dan restribusi sebagai sumber pendapatan yang diperlukan daerah.

Rumus yang digunakan untuk menghitung rasio kemandirian adalah:

RKKD $=\frac{\text { PAD }}{\text { Pendapatan Transfes }} \times 100 \%$

\section{b. Rasio efektifitas PAD}

Rasio Efektivitas PAD menggambarkan kemampuan pemerintahan daerah dalam merealisasikan PAD yang direncanakan dan dibandingkan dengan target yang ditetapkan berdasarkan potensi rill daerah. Semakin tinggi Rasio Efektivitas PAD, maka semakin baik kinerja pemerintahan daerah. 
Rumus yang digunakan untuk menghitung Rasio Efektivitas PAD adalah:

Rasio Efektivitas PAD $=\frac{\text { Realisasi PAD }}{\text { Anggaran PAD }} \times 100 \%$

\section{c. Rasio keserasian}

Rasio Keserasian menggambarkan bagaimana pemerintahan daerah memprioritaskan alokasi dananya pada belanja operasi dan belanja modal secara optimal. Secara sederhana rasio keserasian itu dapat diformulasikan sebagai berikut:

1) Rasio Belanja Operasi terhadap Total Belanja

Rasio belanja operasi merupakan perbandingan antara total belanja operasi dengan total belanja daerah. Rasio belanja operasional dirumuskan sebagai berikut:

Rasio Belanja Operasi $=\frac{\text { Total Belanja Operasional }}{\text { Total Belanja Darah }} \times 100 \%$

\section{2) Rasio belanja modal terhadap total belanja}

Rasio belanja modal merupakan perbandingan antara total realisasi belanja modal dengan total belanja daerah. Rasio belanja modal dirumuskan sebagai berikut:

Rasio Belanja Modal $=\frac{\text { Total Belanja Modal }}{\text { Total Belanja Daerah }} \times 100 \%$

\section{d. Rasio derajat desentralisasi fiskal}

Rasio ini menunjukan derajat kontribusi PAD terhadap total pendapatan daerah. Semakin tinggi kontribusi PAD maka semakin tinggi kemampuan pemerintah daerah dalam penyelenggaraan desentralisasi. Rasio derajat desentralisasi fiskal dapat dihitung dengan menggunakan rumus sebagai berikut:

DDF $=\frac{\text { PADt }}{\text { TPDt }} \times 100 \%$

e. Rasio ketergantungan keuangan

Rasio ketergantungan keuangan dihitung dengan membandingkan jumlah pendapatan transfer yang diterima oleh penerimaan daerah dengan total pendapatan daerah. Ketergantungan keuangan dihitung dengan formula sebagai berikut:

RKK $=\frac{\text { Pendapatan transfer }}{\text { total pendapatan daerah }} X 100 \%$

f. Rasio kemampuan membayar kembali pinjaman (debt service coverage ratio)

Debt Service Coverage Ratio (DSCR) merupakan rasio untuk mengukur kemampuan pemerintah daerah dalam membayar kembali pinjaman daerah. Rasio ini sangat diperlukan apabila pemerintah daerah berencanauntuk mengadakan utang jangka panjang.

Rasio DSCR ini dirumuskan sebagai berikut:

DSCR $=\frac{\text { (PAD+BD+DAU) }- \text { BW }}{\text { Total (Pokolk Angsuran+Bunga+Biaya Pinjaman) }}$ 


\section{g. Rasio efisiensi keuangan daerah}

Rasio Efisiensi Keuangan Daerah menggambarkan perbandingan antara besarnya biaya yang dikeluarkan untuk memperolah pendapatan dengan realisasi pendapatan yang diterima. Rumus yang digunakan untuk menghitung rasio efisiensi keuangan daerah adalah:

$$
\text { REKD }=\frac{\text { Reslisasi Belanja Daerah }}{\text { Realisasi Pendapatan Daerah }} \times 100 \%
$$

\section{h. Rasio pertumbuhan}

Rasio ini mengukur seberapa besar kemampuan pemerintahan daerah dalam mempertahankan dan meningkatkan keberhasilanya yang telah dicapai dari satu periode ke periode berikutnya.

Rumus yang digunakan untuk menghitung rasio pertumbuhan adalah:

$$
\mathrm{r}=\frac{\mathrm{Pn}_{\mathrm{n}}-\mathrm{P}_{0}}{\mathrm{P}_{\mathrm{o}}}
$$

\section{Teknik Analisis Data}

Teknik analisis digunakan untuk menginterprestasikan dan menganalisis data. Sesuai dengan metode yang dikembangkan dalam penelitian ini maka alat analisis data yang digunakan adalah SEM (structural equation modeling), yang dioperasikan melalui program PLS (Partial Least square). Dengan menggunakan metode SEM akan memudahkan analisis secara simultan, lebih ringkas dan efisien. PLS adalah salah satu metoda statistik SEM berbasis varian yang didesain untuk menyelesaikan regresi berganda ketika terjadi permasalahan spesifik pada data, seperti ukuran sampel penelitian kecil, adanya data yang hilang (missing values) dan multikolinearitas.

Uji hipotesis digunakan untuk menjelaskan arah hubungan antara variabel independen dan variabel dependennya. Pengujian ini dilakukan dengan cara analisis jalur (path analysis) atas model yang telah dibuat. Program WarpPLS 6.0 dapat secara simultan menguji model struktural yang komplek, sehingga dapat diketahui hasil analisis jalur dalam satu kali analisis regresi. Hasil korelasi antar konstruk diukur dengan melihat path coefficients dan tingkat signifikansinya yang kemudian dibandingkan dengan hipotesis penelitian yang terdapat pada bab dua. Suatu hipotesis dapat diterima atau harus ditolak secara statistik dapat dihitung melalui tingkat signifikansinya. Biasanya tingkat signifikansi ditentukan sebanyak $10 \%, 5 \%$, dan $1 \%$. Tingkat signifikansi yang dipakai dalam penelitian ini adalah sebesar 5\%. Apabila tingkat signifikansi yang dipilih sebesar 5\% maka tingkat signifikansi atau tingkat kepercayaan 0,05 untuk menolak suatu hipotesis. Dalam penelitian ini ada kemungkinan mengambil keputusan yang salah sebesar $5 \%$.

\section{Hasil dan Pembahasan}

\section{Validitas konvergen}

Validitas konvergen menunjukkan sejauh mana suatu ukuran berkorelasi positif dengan ukuran konstruk alternatif yang sama (Hair, et al., 2014). Ada dua kriteria (Sholihin dan Ratmono, 2013; Mahardhika, 2019) untuk menilai apakah model pengukuran memenuhi persyaratan validitas konvergen untuk konstruksi reflektif yaitu memuat nilai $>0,70$ dengan p signifikan (nilai <0,05); atau nilai rata-rata diekstraksi nilai (AVE) $\geq 0,50$.

Tabel 3 menunjukkan nilai pemuatan, nilai $\mathrm{p}$, dan AVE untuk masing-masing membangun. Dapat dilihat bahwa indikator KIN2, KIN3, KIN6, KIN7 dan KIN8 telah dikeluarkan dari model karena nilai pemuatan di bawah 0,04. Namun demikian masih dipertahankan 
indikator yang memiliki nilai pemuatan antara 0,04-0,07. Prosedur yang disarankan menyatakan bahwa keputusan untuk menghapus indikator dengan nilai pemuatan antara 0,04-0,07 didasarkan pada dampak dari keputusan untuk menghapus indikator tersebut pada AVE dan komposit reliability. Indikator tersebut dapat dihapus jika berdampak pada peningkatan AVE dan keandalan komposit di atas batasnya (Sholihin dan Ratmono, 2013; Mahardhika, 2019)

Tabel 3 Convergent validity

\begin{tabular}{|c|c|c|c|c|}
\hline & item & loading & p-value & AVE \\
\hline \multirow{3}{*}{ Kinerja Keuangan } & KIN1 & $(0,948)$ & $<0,001$ & \\
\hline & KIN4 & $(0,583)$ & $<0,001$ & 0,716 \\
\hline & KIN5 & $(0,953)$ & $<0,001$ & \\
\hline $\begin{array}{l}\text { Alokasi Belanja } \\
\text { Modal }\end{array}$ & ABM1 & $(1,000)$ & $<0,001$ & 1,000 \\
\hline $\begin{array}{l}\text { Pertumbuhan } \\
\text { Ekonomi }\end{array}$ & PE2 & $(1,000)$ & $<0,001$ & 1,000 \\
\hline
\end{tabular}

Sumber : Data Yang Diolah (2019)

\section{Validitas deskriminan}

Validitas diskriminan menunjukkan sejauh mana konstruk benar-benar berbeda dari konstruk lain berdasarkan standar empiris (Hair, et al., 2014). Kriteria yang digunakan untuk menilai apakah model pengukuran memenuhi persyaratan validitas diskriminan adalah nilai akar kuadrat Average Varience Ekstacted (AVE) yaitu kolom diagonal dan diberi tanda kurung harus lebih tinggi dari korelasi antara variabel laten di kolom yang sama (Sholihin \& Ratmono, 2013).

Table 4. Discriminant validity

\begin{tabular}{crrr}
\hline & $\begin{array}{c}\text { Kinerja } \\
\text { Keuangan }\end{array}$ & $\begin{array}{c}\text { Alokasi Belanja } \\
\text { Modal }\end{array}$ & $\begin{array}{c}\text { Pertumbuhan } \\
\text { Ekonomi }\end{array}$ \\
\hline Kinerja Keuangan & $(0,846)$ & 0,583 & 0,026 \\
Alokasi Belanja Modal & 0,583 & $(1,000)$ & $-0,004$ \\
Pertumbuhan Ekonomi & 0,026 & $-0,004$ & $(1,000)$ \\
\hline
\end{tabular}

Sumber : Data yang diolah (2019)

Tabel 4 menunjukkan bahwa persyaratan validitas diskriminan telah dipenuhi. Dapat dilihat bahwa nilai akar kuadrat AVE (kolom diagonal) lebih tinggi dari pada korelasi antara variabel laten dalam kolom yang sama.

\section{Reliabilitas konsistensi internal}

Tes reliabilitas konsistensi internal dilakukan untuk menilai homogenitas antara item yang membentuk sebuah konstruk (Cooper dan Schindler, 2011). Kriteria yang digunakan untuk menilai reliabilitas konsistensi internal adalah nilai composit reliability dan cronbach's alpha di atas 0,70 (Sholihin dan Ratmono, 2013).

Tabel 5. Internal consistency reliability

\begin{tabular}{ccccc}
\hline & $\begin{array}{c}\text { Kinerja } \\
\text { Keuangan }\end{array}$ & $\begin{array}{c}\text { Alokasi } \\
\text { Belanja } \\
\text { Modal }\end{array}$ & $\begin{array}{c}\text { Pertumbuhan } \\
\text { Ekonomi }\end{array}$ & Keterangan \\
\hline $\begin{array}{c}\text { composite } \\
\text { reliability }\end{array}$ & 0,879 & 1,000 & 1,000 & Reliabel \\
\hline cronbach's alpha & 0,782 & 1,000 & 1,000 & Reliabel \\
\hline
\end{tabular}


Sumber : Data yang diolah (2019)

Berdasarkan tabel 5 , menunjukan composite reliability dari masing-masing kontruk, yaitu kinerja keuangan $(0,879)$, alokasi belanja modal $(1,000)$, pertumbuhan ekonomi $(1,000)$. Hasil dari cronbach's alpha juga menunjukan bahwa kinerja keuangan $(0,782)$, alokasi belanja modal $(1,000)$, pertumbuhan ekonomi $(1,000)$. Berdasarkan hasil dari composite reliability dan cronbach's alpha, dapat disimpulkan bahwa keseluruhan variabel telah memenuhi kreteria composite reliability.

\section{Uji hipotesis}

Hipotesis dalam penelitian ini diuji menggunakan SEM-PLS 6.0. Ada dua hipotesis yang diuji dalam penelitian ini. Hipotesis didukung jika p-value $<0,05$ (signifikan pada tingkat $5 \%$ ). Tabel di bawah ini menyajikan ringkasan hasil pengujian hipotesis penelitian ini.

Tabel 6. Hypothesis testing

\begin{tabular}{ccccc}
\hline & & $\begin{array}{c}\text { Path } \\
\text { Coefficient }\end{array}$ & P-Value & Result \\
\hline $\mathrm{H} 1$ & $\begin{array}{c}\text { Kinerja Keuangan -> } \\
\text { Alokasi belanja modal }\end{array}$ & 0,647 & 0,001 & Accepted \\
\hline $\mathrm{H} 2$ & $\begin{array}{c}\text { Kinerja Keuangan -> } \\
\text { Pertumbuhan Ekonomi }\end{array}$ & 0,187 & 0,023 & Accepted \\
\hline
\end{tabular}

Sumber : Data yang diolah (2019)

Hasil pengujian hipotetsis menggunakan Warp-PLS, membuktikan bahwa kedua hipotesis dalam penelitian ini diterima ( $\mathrm{P}$-value $<0,05)$, dengan demikian dapat disimpulkan bahwa 1 ) kinerja keuangan berpengaruh positif pada alokasi belanja modal. Hasil penelitian ini mengidentifikasikan bahwa setiap perubahan kinerja keuangan berupa rasio kemandirian keuangan daerah, rasio belanja modal, dan rasio derajat desentralisasi fiskal Kabupaten/Kota di Provinsi Jawa Tengah akan berdampak kepada perubahan alokasi belanja modal di Kabupaten/Kota di Provinsi Jawa Tengah. 2) kinerja keuangan berpengaruh positif pada pertumbuhan ekonomi. Penelitian ini mengidentifikasikan bahwa setiap perubahan kinerja keuangan berupa rasio kemandirian keuangan daerah, rasio belanja modal, dan rasio derajat desentralisasi fiskal Kabupaten/Kota di Provinsi Jawa Tengah akan berdampak pada perubahan pertumbuhan ekonomi Kabupaten/Kota di Provinsi Jawa Tengah.

\section{Penutup dan Saran}

\section{Simpulan}

Pengalokasian belanja modal yang dilakukan oleh pemerintah kabupaten/kota di Provinsi Jawa Tengah dipengaruhi oleh kinerja keuangan khususnya rasio kemandirian keuangan daerah, rasio belanja modal, dan rasio derajat desentralisasi fiskal. Hal ini berarti bahwa semakin baik kinerja keuangan pemerintah daerah maka semakin tinggi alokasi belanja modalnya.

Pertumbuhan ekonomi dipengaruhi oleh kinerja keuangan khususnya rasio kemandirian keuangan daerah, rasio belanja modal, dan rasio derajat desentralisasi fiskal. Dengan demikian dapat dinyatakan bahwa dengan otonomi daerah, muncul indikator lain yang mendukung pertumbuhan ekonomi yaitu kinerja keuangan daerah, selain tiga faktor utama 
pertumbuhan ekonomi yaitu akumulasi belanja modal, pertumbuhan penduduk, dan hal-hal yang berhubungan dengan kenaikan jumlah angkatan kerja.

\section{Saran}

Bagi Pemerintah Kabupaten/Kota di Provinsi Jawa Tengah sebaiknya berkonsentrasi untuk dapat meningkatkan dan menggali sumber-sumber PAD terutama pendapatan yang bersumber dari pajak dan restribusi daerah dengan tujuan agar dapat membiayai belanja daerahnya sendiri. Semakin meningkat penerimaan asli daerah tentunya akan menunjukan kinerja keuangan pemerintah daerah yang semakin baik. Selain itu, pemerintah juga harus terus berupaya mengurangi transfer dana perimbangan dari pemerintah pusat sebagai wujud kemandirian daerah dalam membiayai belanjanya dan untuk mengurangi ketergantungan terhadap pemerintah pusat.

Bagi Pemerintah Kabupaten/Kota di Provinsi Jawa Tengah sebaiknya lebih terampil lagi dalam mengontrol rencana dan realisasi PAD agar pertumbuhan PAD dari tahun ke tahun dapat mempengaruhi kenaikan pertumbuhan ekonomi dan harus dapat meningkatkan kesadaran masyarakat sebagai wajib pajak atau wajib restribusi untuk memenuhi kewajibannya sehingga dapat meningkatkan PAD di daerahnya.

Bagi Pemerintah Kabupaten/Kota di Provinsi Jawa Tengah agar lebih memperbesar pengalokasian dana untuk pembangunan yang dapat memberikan pengaruh langsung bagi pendapatan daerah dan pertumbuhan ekonomi.

\section{Referensi}

Bastian, I. (2010). Akuntansi Sektor Publik. Edisi Ketiga. Penerbit Eirlangga. Jakarta.

Cooper, D. R., \& Schindler, P. S. (2006). Business Research Methods. 11 th Edition. New York: McGraw-Hill Companies Inc.

Hair Junior, J. F., Hult, G. T. M., Ringle, C. M., \& Sarstedt, M. (2014). A Primer on Partial Least Squares Structural Equation Modeling (PLS-SEM). California, USA: SAGE Publications Inc.

Halim, A. (2012). Pengelolaan Keuangan Daerah. Edisi Ketiga. Yogyakarta: UPP STIM YKPN.

Halim, A.(2018) Analisis Investasi (Belanja Modal) sektor Publik-Pemerintah Daerah. Yogyakarta: UPP STIM YKPN.

Latuny, E. M. (2016). Analisis Perkembangan Kemapuanan Keuangan Daerah Terhadap Pelaksanaan Otonomi (Study Kasusu Kabupaten Maluku Tenggara Barat). Cita Ekonomi Jurnal Ekonomi, 10(1), 97-103.

Machmud, M. (2014). Analisis Kinerja Keuangan Daerah Di Provinsi Sulawesi Utara Tahun 2007-2012. Jurnal berkala ilmiah efisiensi, 14(2), 1-13.

Mahardhika, A. S. (2019). Akuntan di Era Digital: Pendekatan TAM (Technology Acceptance Model) Pada Software Berbasis Akuntansi. Jurnal Ilmiah Akuntansi dan Keuangan, 8(1), 12-16.

Mahmudi. (2010). Analisis LaporanKeuangan Pemerintah Daerah. Yogyakarta: UPP STIM YKPN. 
Mahmudi. (2016). Kinerja Keuangan Pemerintah Daerah. Yogyakarta: UPP STIM YKPN.

Mahsun, M. (2010). Akuntansi Sektor Publik. Edisi Kedua. Cetakan Pertama. Yogyakarta: BPFE.

Mahsun, M. (2012). Pengukuran Kinerja Sektor Publik. Edisi Ketiga. Yogyakarta: BPFE.

Peraturan Gubernur Jawa Tengah No 06 Tahun 2017 tentang perubahan kedua atas Peraturan Gubernur Jawa Tengah No 43 Tahun 2015 tentang pemberian Tambahan Penghasilan Pegawai (TPP) di lingkungan pemerintahan Jawa Tengah.

Peraturan Mentri Dalam Negeri No. 59 tahun 2007 tentang perubahan pertama pemendagri No. 13 tahun 2006 tentang pedoman pengelolaan keuangan daerah.

Rahmawati, N. K. E., \& Putra, I. W. (2016). Analisis Kinerja Keuangan Pemerintah Kabupaten Sumbawa Tahun Anggaran 2010-2012. E-Jurnal Akuntansi, 1767-1795.

Rasdalima1, R. J., Luntungan, Y. A., \& Wauran, P. C. (2017). Analisis Pengaruh Pengelolaan Keuangan Daerah Terhadap Pertumbuhan Ekonomi Provinsi Sulawesi Utara. Jurnal Berkala Ilmiah Efisiensi, 17(1), 134-145.

Sartika, N., Kirmizi, K., \& Indrawati, N. (2017). Analisis Faktor-faktor dalam Struktur APBD dan Kinerja Keuangan Daerah yang Mempengaruhi Belanja Modal pada Kabupaten/Kota di Provinsi Riau. Sorot, 12(2), 121-135.

Sholihin, M. dan Ratmono, D. (2013) Analisis SEM-PLS dengan WarpPLS 3.0 Untuk Hubungan Nonlinear dalam Penelitian Sosial dan Bisnis. Yogyakarta: Andy Offset.

Sularso, H., \& Restianto, Y. E. (2012). Pengaruh kinerja keuangan terhadap alokasi belanja modal dan pertumbuhan ekonomi kabupaten/kota di Jawa Tengah. Media Riset Akuntansi, 1(2).

Undang-Undang Republik Indonesia Nomor 32 Tahun 2004 Pemerintahan Daerah. 15 Oktober 2004. Jakarta.

Undang-Undang Republik Indonesia Nomor 33 Tahun 2004 Perimbangan Keuangan Antara Pemerintah Pusat dan Pemerintah Daerah. 15 Oktober 2004.

Wiyono, G. (2011). 3 In One: Merancang Penelitian Bisnis Dengan Alat Analisis SPSS 17.0 E SmartPLS 2.0. Edisi 1. Yogyakarta. UPP STIM YKPN. 